\title{
Unusual Spherical Bodies in Bone Marrow of a Patient with Monoclonal Gammopathy of Undetermined Significance
}

\section{Önemi Belirlenemeyen Monoklonal Gammopatili Bir Hastanın Kemik Iliğinde Olağandışı Küresel Cisimcikler}

(D) Habib Moshref Razavi1,2

${ }^{1}$ Royal Columbian Hospital, Department of Pathology, New Westminster, British Columbia, Canada

${ }^{2}$ British Columbia University, Department of Pathology and Laboratory Medicine, Vancouver, British Columbia, Canada
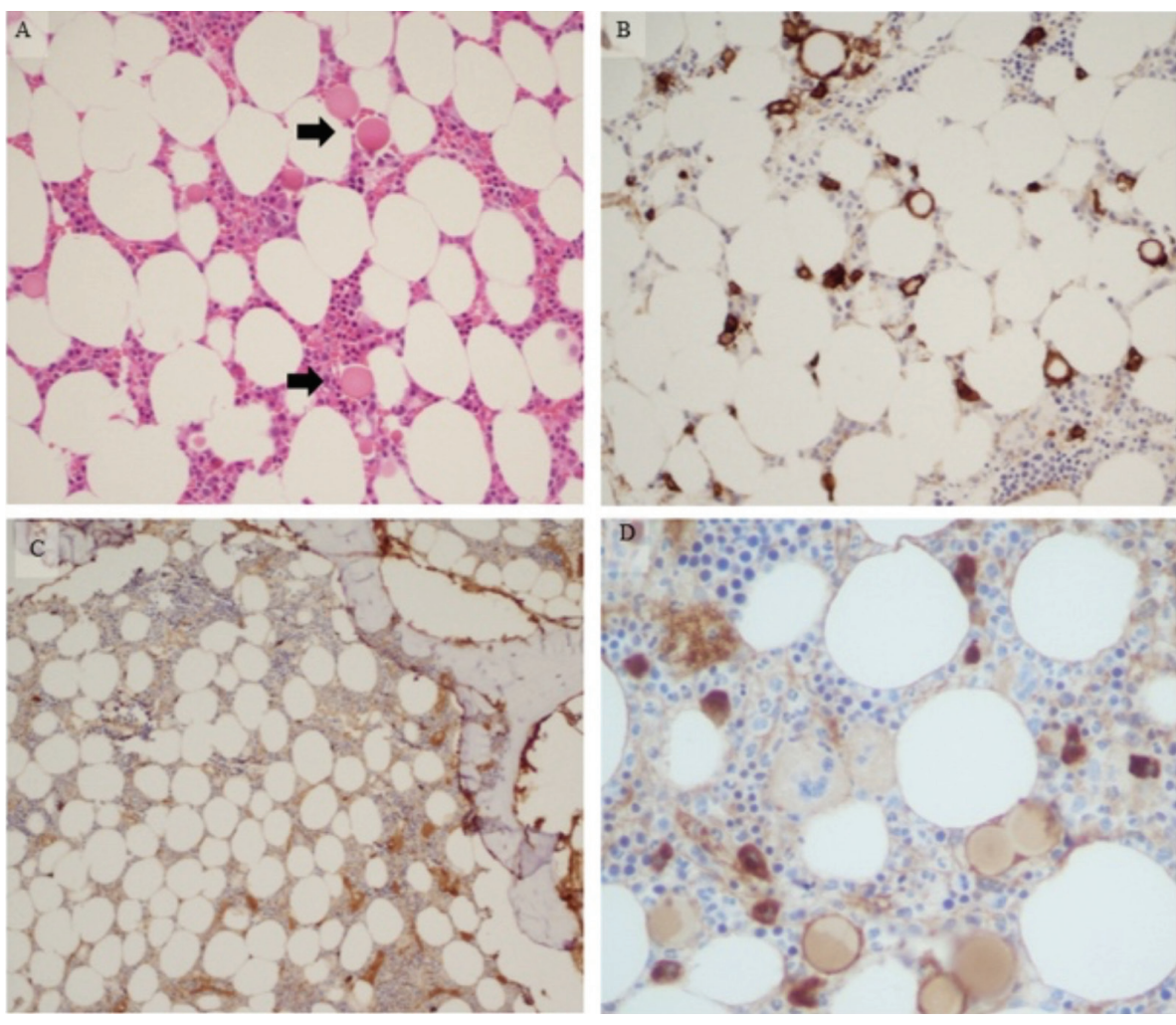

Figure 1. Bone marrow trephine biopsy, 10x (A). H\&E shows normocellular bone marrow where large/giant spherical entities are noted (black arrows in $A)$. CD138 (B, 20x) and kappa $\left(C, 10^{x}\right) /$ lambda $\left(D, 40^{x}\right)$ stains show that large spherical bodies are not cellfree structures and exist as giant spherical plasma cells with overstuffed/ballooning cytoplasm with cellular effacement. 
A 78-year-old male patient with mild cytopenias (hemoglobin $120 \mathrm{~g} / \mathrm{L}$ with platelet count of $114 \times 109 / \mathrm{L}$ ) and low lambda clonal paraprotein $(6.9 \mathrm{~g} / \mathrm{L})$ is described. A bone marrow biopsy showed the presence of trilinear hematopoiesis with occasional plasma cells $(<10 \%)$. A trephine biopsy showed the presence of large spherical bodies (Figure 1A, black arrows), which were proved not to be cell-free by CD138/kappa/lambda stains, existing as inclusions in lambda-restricted plasma cells (Figures 1B-1D). With $<10 \%$ clonal plasmacytosis, lack of end organ damage, and paraprotein at $<30 \mathrm{~g} / \mathrm{L}$, monoclonal gammopathy of undetermined significance was diagnosed. Plasma cell inclusions were first described by Russell in 1890 [1]. Inclusions in the cytoplasm (Russell bodies) and overlaying the nucleus (Dutcher bodies) usually leave the cellular morphology intact. H\&E morphology and immunohistochemistry in this case showed complete cellular effacement with cytoplasmic ballooning. A variety of intracytoplasmic inclusions have been reported and include mulberry-type inclusions in Mott cells, vermillion-tinged deposits in immunoglobulin A-type flame cells, and even Auer rod-like inclusions [2]. The nature of the inclusions has been elucidated as amalgamation of condensed immunoglobulins in dilated vesicles associated with ER cisternae. The significance of their presence in disease progression is unknown.

Keywords: Monoclonal gammopathy of undetermined significance, Plasma cell inclusions, Russell bodies, Immunohistochemistry

Anahtar Sözcükler: Önemi belirlenemeyen monoklonal gammopati, Plazma hücre inklüzyonları, Russell cisimsikleri, İmmünohistokimya

Financial Disclosure: The author declared that this study received no financial support.

\section{References}

1. Russell W. An address on characteristic organism of cancer. Br Med J 1890;2:1356-1360.

2. Metzgeroth G, Back W, Maywald O, Schatz M, Willer A, Hehlmann R, Hastka J. Auer rod-like inclusions in multiple myeloma. Ann Hematol 2003;82:5760. 